\title{
Effects of Medicinal Enzyme Powder on Intestinal Mobility, Lipid Level, and Blood Parameters of Loperamide-Induced Constipation in Rats
}

\author{
Chan Sung Park, Kyung Soo Park, Mi Lim Kim, Hyun Joo Kong and Kyung Mi Yang* \\ Faculty of Herbal Food Cooking \& Nutrition, Daegu Haany University, Gyeongsan 712-715, Korea
}

Received November 12, 2012 /Revised January 30, 2013 / Accepted February 6, 2013

\begin{abstract}
This study was aimed at investigating whether dietary therapy using medicinal enzyme powder is effective in reducing constipation caused by loperamide in rats. Nine-week-old male Sprague Dawley were subdivided into 4 groups: normal diet group (C), loperamide treatment and normal diet (CL), medicinal enzyme powder diet $(\mathrm{E})$, and loperamide treatment and medicinal enzyme powder diet (EL). Constipation was induced by subcutaneous injection of loperamide $(1.5 \mathrm{mg} / \mathrm{kg}) 3$ days prior to sacrifice. The treatment with loperamide led to an increase in weight gain, a decrease in the number and wet weight of fecal pellets, and a decrease in intestinal motility. The administration of the medicinal enzyme powder significantly reduced weight gain but increased intestinal mobility compared with the loperamide-treated group. The treatment with loperamide in the normal diet group reduced the activities of both suggesting that constipation may be involved in the low level of glutamic oxaloacetic transaminase (GOT) and glutamic pyruvic transaminase (GPT). Additionally, the loperamide treatment in the medicinal enzyme powder diet group increased the level of GOT, but reduced the level of GPT. Loperamide treatment also reduced cholesterol and increased the atherogenic index (AI) and cardiac risk factors (CRFs). Interestingly, the treatment with the medicinal enzyme powder effectively attenuated both the increase in AI and the reduction in high density lipopretein (HDL)-cholesterol, caused by the treatment with loperamide. Although there were no significant differences in the blood protein level, including hemoglobin and hematocrit, between the normal diet group and the loperamide-treated group, the administration of the medicinal enzyme powder to the loperamide-treated group effectively increased the levels of both hemoglobin and hematocrit. Collectively, the results demonstrate that the medicinal enzyme powder can help to combat the negative events caused by constipation.
\end{abstract}

Key words : Medicinal enzyme powder, constipation, intestinal motility, lipid level, blood parameter

\section{서 론}

만병의 근원으로 알려진 변비의 유병률은 외국에서는 $15 \%$, 한국 경우는 $16.5 \%$ 로 보고되고 있으나[27, 35], 최근에는 스트 레스, 고지방이나 저 섬유질의 서구식 식사, 그리고 부적절한 생활습관 등으로 증가되고 있다[19]. 변비진단 기준은 의학적 으로 주 2회 이하의 배변 횟수이거나 $35 \mathrm{~g}$ 미만의 적은 양의 변을 보는 경우를 말하며, 증상으로는 다수의 환자가 배변 횟 수는 정상범위이나 변을 볼 때 과도한 힘주기, 딱딱한 변, 잔변 감, 직장항문 폐색감과 같은 배변곤란을 호소한다[25]. 또한 일부 환자들은 원활한 배변을 위한 약물 복용이나 복부 마사 지와 같은 부가적인 처치를 시행하고 있다[22]. 변비는 흔하게

\footnotetext{
*Corresponding author

Tel : +82-53-819-1490, Fax : +82-53-819-1494

E-mail : jiboosin@dhu.ac.kr

This is an Open-Access article distributed under the terms of the Creative Commons Attribution Non-Commercial License (http://creativecommons.org/licenses/by-nc/3.0) which permits unrestricted non-commercial use, distribution, and reproduction in any medium, provided the original work is properly cited.
}

나타나는 소화기계 증상 중의 하나로 식욕저하, 복부팽만이나 구토증상 등으로 이 자체가 생활의 불편함을 초래한다. 그리 고 변비나 독성물질로 인하여 장내 염증이 발생한 경우 음식 물의 노폐물이나 발암물질 및 장내 이상 발효로 생성된 황화 수소, 니트로소아민, 암모니아, 페놀 등이 혈관으로 흡수됨으 로써 여드름, 각종 피부 질환이나 피부 노화, 두통, 알레르기, 우울증, 치질이나 대장암, 뇌졸증, 협심증, 심근경색 등 심혈관 계 질환, 면역결핍 등 다양한 질환을 일으킨다. 심한 경우에는 대장암 등 다른 질병의 유발 요인으로 작용하므로 삶의 질을 저하시키고 있다[5, 32].

변비의 예방 및 치료방법으로는 충분한 식이섬유소와 수분 섭취, 유산균 음료섭취와 같은 식이요법, 운동요법, 약물요법, 관장요법 등이 있다[29]. 식이요법 중에서 채소류, 버섯류, 과 일 및 해조류에 함유된 식이섬유소는 미생물의 성장과 분해산 물 증가로 수분 보유력 증가, 장 통과시간의 감소 및 배변량 증가 등의 작용을 통하여 변비에 효과적이다[3]. 이외에도 유 기산 함량이 높은 과일, 유당이 함유된 우유 등이 프리바이오 틱(prebiotics)로 변비 예방 및 치료식이로 보고되고 있다[3]. 최근에는 변비예방과 치료 개선을 위하여 숙주에게 살아있는 
미생물을 일정수준 섭취시켜 유익한 균총을 형성하여 숙주의 유익한 장내 환경을 제공하는 프로바이오틱(probiotics)의 섭 취 중요성이 강조되고 있다. 이외에도 생체 내 각종 화학반응 의 촉매제로 작용하여 소화활동 증진, 면역기능 강화, 및 신진 대사력을 증진시키는 효소식품과 같은 변비 예방과 치료를 위한 건강기능성 식품의 개발과 연구도 활발히 진행되고 있다 $[8,39]$. 특히 효소식품의 복용은 100 종의 100 조 마리에 이르는 균총이 있는 대장에 유익한 세균총을 형성하여 대장의 건강과 더 나아가서 신체 전체의 건강을 좌우하는 중요한 물질로 보 고되고 있다[15].

따라서 본 연구에서는 loperamide로 변비를 유발시킨 실험 동물에게 현미, 보리, 율무, 백태로 이루어진 혼합 곡류물에 황국균으로 접종하여 발효 및 건조시킨 곡류 효소 발효 분말 과 줄풀, 민들레, 하수오 등의 한약재 발효 혼합농축액, 그리고 기타 베타글루칸, 프락토올리고당, 클로렐라를 일정비율로 혼 합시켜 만든 약선효소 제품을 일정기간 공급시켰다. 그런 다 음 loperamide로 유발된 변비 쥐의 장 운동성, 고지혈증 지표 성분 그리고 혈액학적 성분 변화에 대한 약선효소의 효과를 규명하고자 한다. 더 나아가서 약선효소 기능성식품으로 연결 된 산업화로 경제적 이익 창출과 변비의 예방으로 사망률이 높은 심혈관계 질환과 암의 발병률을 줄이고 변비에 대한 식 단개발을 위한 기초자료로 활용하고자 실시하였다.

\section{재료 및 방법}

\section{식이 재료 및 시약}

약선효소 시료는 경북 청도군 청도읍에 소재해 있는 (주)시 월에프엔디에서 제공 받아 $-70^{\circ} \mathrm{C}$ 에서 냉동보관하면서 식이로 사용하였다. 제공받은 약선효소 시료는 일정비율의 현미, 보 리, 율무, 그리고 백태 혼합물에 황국균으로 접종하여 발효
및 건조시켜 제조한 효소분말 $70 \%$ 와 줄풀, 민들레, 도라지, 양파, 생지황, 당귀, 그리고 하수오 혼합물에 당화균으로 발효 시켜 제조한 식물발효 혼합농축액 $9.6 \%$, 그리고 베타글루칸, 클로렐라, 프락토올리고당, 그리고 비타민 혼합물 $20.4 \%$ 로 구 성되어 있다. 변비유도 시약인 loperamide는 Sigma 사(St. Louise, MO, USA) 제품을 사용하였으며, 기타 시약은 일반 특급시약을 사용하였다.

\section{실험동물 사육 및 식이}

실험동물은 200-250 g 정도의 생후 8주령이 된 SpragueDawley종 수컷 흰쥐를 1 주 동안 일반배합 고형사료로 환경에 적응시킨 다음 체중에 따라 각 처리 구당 10 마리씩 4 군으로 완전임의 배치하여 사육하였다. 실험군과 식이조성은 Table 1 과 같이 정상식이군 $(\mathrm{C})$ 과 효소식이군 $(\mathrm{E})$ 에 대한 대조군으로 각각의 변비유도군 $(\mathrm{CL}, \mathrm{EL})$ 으로 나누어서 구성하였다. 정상식 이는 AIN-93 정제식이 조성에 준하여 제조하였으며 효소식이 는 (주)시월에프엔디에서 공급받은 효소분말 상태로 공급하였 다. 실험식이 공급은 3 주 동안 이루어졌다. 실험동물 사육실 환경온도는 $22 \pm 1^{\circ} \mathrm{C}$, 상대습도는 $65 \pm 5 \%$, 명암은 12 시간 주기 (09:00-21:00)로 조절하였다. 물과 식이는 전 실험기간 동안 ad libitum으로 급여하였다. 그런 다음 3일 동안 Park 등[31] 이 사용한 방법에 준하여 loperamide $(1.5 \mathrm{mg} / \mathrm{kg}$, s.c.)를 $0.5 \%$ Tween 20에 녹인 후 1일 2회(오전 9시와 오후 6시)피하로 투여 하여 변비 $(\mathrm{CL}, \mathrm{EL})$ 를 유발하였고, 정상군 $(\mathrm{C}, \mathrm{E})$ 은 $0.9 \%$ 생리식 염수만을 투여하였다. 따라서 3주 동안 효소분말 식이를 섭취 한 다음 3 일 동안 loperamide의 투여로 유도된 변비에 대한 효소분말 식이의 효능실험을 실시 할 수 있었다.

실험동물의 체중과 사료섭취량은 loperamid 투여 전(변비 유발 전, 0-19일)에는 일주일 간격으로 측정하였으나 loperamide 투여 기간(변비 유발기간, 20-23일)에는 매일 일정 시간

Table 1. Composition of experimental diet fed in rats

\begin{tabular}{|c|c|c|c|c|}
\hline \multirow{2}{*}{ Diet composition ( $\mathrm{g} / \mathrm{kg}$ diet) } & \multicolumn{4}{|c|}{ Groups $^{1)}$} \\
\hline & $\mathrm{C}$ & $\mathrm{CL}$ & E & EL \\
\hline Casein & 200 & 200 & - & - \\
\hline DL-methionine & 3.5 & 3.5 & - & - \\
\hline Sucrose & 200 & 200 & - & - \\
\hline Corn starch & 450 & 450 & - & - \\
\hline Cellulose & 50 & 50 & - & - \\
\hline Corn oil & 50 & 50 & - & - \\
\hline Mineral mixture ${ }^{2)}$ & 35 & 35 & - & - \\
\hline Vitamin mixture $^{3)}$ & 10 & 10 & - & - \\
\hline Choline bitartrate & 1.5 & 1.5 & - & - \\
\hline Cholesterol & - & - & - & - \\
\hline Medicinal enzyme powder & - & - & 1000 & 1000 \\
\hline
\end{tabular}

${ }^{1)}$ The Experimental diet groups are as follow. C: normal diet group, CL: normal diet and loperamide-treated group, E: medicinal enzyme powder diet group, EL: medicinal enzyme powder diet and loperamide-treated group.

${ }^{2)}$ Based on AIN-93 vitamin mixture.

${ }^{3)}$ Based on AIN-93G mineral mixture 
에 측정하였다. 사료효율은 사육기간 동안의 체중증가량을 같 은 기간 동안 섭취한 식이섭취량으로 나누어 산출하였다. 전 사육기간 동안 음수량은 매일 $250 \mathrm{ml}$ 의 물을 일정시간에 공급 하며 남은 양을 관찰하여 섭취량을 측정하였다.

\section{채혈 및 장기 적출}

실험동물은 희생하기 전에 12 시간 공복시켰으며 장 운동 력을 평가하기 위하여 활성탄을 경구투여 한 다음 25-30분 후에 ethyl ether를 사용하여 가볍게 마취시킨 후 개복하여 복부대동맥에서 헤파린 처리된 주사기를 통하여 전혈을 취 하였다. 그런 다음 장을 적출하여 지방을 제거한 후 생리식 염수에 세척 후 길이를 측정하였다. 간은 $1.15 \% \mathrm{KCl}$ 완충액 에 perfusion 시켜 혈액을 제거한 후 여과지로 습기를 제거 하였다. 채혈한 혈액을 $2,000 \mathrm{~g}$ 에서 10 분 동안 원심분리 한 다음 얻은 혈장과 적출한 간 조직은 분석 할 때까지 $-70^{\circ} \mathrm{C}$ 에 서 보관하였다.

\section{변의 갯수, 변 중량, 변의 수분함량 및 장 운동성 평가}

각 실험동물의 변은 변비유도 기간 그리고 희생 전에 변 을 수거하여 개체 당 변의 개수와 변 중량과 변의 수분량을 측정하였다. 변의 수분함량은 $70^{\circ} \mathrm{C}$ 오븐에서 24 시간 동안 건 조시켜 건 중량을 측정하고 변 중량과 건 중량의 차이를 변 중량으로 나누어 계산하였다. 실험동물의 장내 변의 개수는 loperamide 투여 후 4 일째 되는 날 희생시킨 후 맹장에서 직 장까지의 전 부위에 잔류하고 있는 변의 개수를 세어 확인하 였다.

장의 운동성 평가는 생리적 식염수를 이용하여 만든 5\% 활성탄 용액을 $0.5 \mathrm{ml}$ 씩 경구투여 하고 25-30분 후에 개복하 여 위의 유문부부터 대장의 하단부인 항문까지를 적출하여 활성탄의 이동률로 확인하였다. 방법으로는 Cho [4] 등의 방 법을 응용하여 유문부 부터 대장의 하단부인 항문까지를 총 장길이(total length of intestine)로 하고, 활성탄이 유문부로부 터 이동한 길이(travel length of charcol)를 확인하여 백분율로 나타내었다.

$\mathrm{T}(\%)=\mathrm{B} / \mathrm{A} \times 100$

$\mathrm{T}$ : 투여한 활성탄의 소화관 이동률

$\mathrm{A}$ : 위의 유문부부터 대장의 항문까지의 길이

$\mathrm{B}$ : 활성탄의 최선단부까지 이동거리

\section{간 기능지표 검사}

간 손상지표로 혈장 중 GOT (glutamic oxaloacetate transaminase)와 GPT (glutamic pyruvate transaminase)활성도는 GOT와 GPT 활성 측정용 kit (Asan Pharma. Korea)를 이용하 여 측정하였으며, 활성은 Karmen unit로 나타내었다.

\section{지질성분 분석}

혈장 내 중성지질 함량은 glycerol-3-phosphate oxidase-PAP 효소법을 이용하여 제조된 중성지질 측정용 kit (Asan Pharma. Korea), 총 콜레스테롤 함량은 콜레스테롤 가 수분해 효소로 콜레스테롤과 지방산으로 분해하여 측정하는 총 콜레스테롤 측정용 kit (Asan Pharma. Korea), 그리고 HDL-콜레스테롤 함량은 LDL-콜레스테롤을 침전시킨 후 상 층의 HDL-콜레스테롤을 정량하여 측정하는 kit (Asan Pharma. Korea)로 분석하였다. 그리고 LDL-콜레스테롤 함량 은 Friedewald [7] 법에 의거하여 LDL-콜레스테롤=총 콜레스 테롤-HDL콜레스테롤-(중성지방/5) 식으로 계산하였다. 이 측 정치로부터 동맥경화지수(atherogenic index: $\mathrm{AI}$ )는 Haglund [9] 등의 방법에 따라서 $\mathrm{AI}=($ 총 콜레스테롤-HDL-콜레스테 롤)/HDL-콜레스테롤로 계산하였고, 심혈관계지수(cardiac risk factor: $\mathrm{CHR}$ )는 Bang 등[2]의 방법에 따라서 $\mathrm{CHR}=$ 총 콜 레스테롤/HDL-콜레스테롤로 구하였다.

\section{혈액학적 성분검사}

혈장 내 총 단백과 알부민 함량은 색소결합법을 이용한 kit (Embiel, Korea)로 측정하였으며, 글로불린 함량은 총 단백 함 량에서 알부민 함량을 제한 값으로 산출하였다. 빈혈지표로 헤모글로빈 농도와 헤마토크리트치는 Hemochroma reader기 (Boditech, Korea)를 이용하여 측정하였고, 혈 당 측정은 glucose oxidase의 법으로 제조된 포도당 측정용 시약인 gucose-e kit (YD Diagonostics, Korea)을 사용하여 $505 \mathrm{~nm}$ 에서 비색 정 량하였다.

\section{통계분석}

실험을 통하여 얻어진 자료는 SPSS 통계 package (version $14.0)$ 를 이용하여 분석하였으며 그 결과는 평균표준편차 (standard error)로 표시하였다. 실험결과는 일원배치 분산분 석(one way analysis of variance)을 한 후 Duncan's multiple-range test에 의해 $a=0.05$ 수준에서 각 실험군의 평균치의 통계적 유의성을 검정하였다.

\section{결과 및 고찰}

\section{성장상태}

실험동물의 일일 체중증가량, 식이효율 및 수분섭취량 결과 는 Table 2 와 같다. 일일 체중증가량은 정상식군 $(\mathrm{C})$ 은 $1.11 \pm$ $0.74 \mathrm{~g} /$ day, 정상식 변비군 $(\mathrm{CL})$ 은 $1.72 \pm 0.88 \mathrm{~g} /$ day로 이들 두 군 사이에는 유의적인 차이는 없었다. 그러나 효소식군(E)과 효소식 변비군(EL)은 각각 $1.78 \pm 1.39 \mathrm{~g} /$ day $0.78 \pm 0.53 \mathrm{~g} /$ day 으로 이들 두 군 사이에는 $p<0.05$ 수준에서 유의적인 차이를 보였다. 변비군 $(\mathrm{CL}, \mathrm{EL})$ 의 일일 체중증가량은 정상식 변비군 $(\mathrm{CL})$ 은 $1.72 \pm 0.88 \mathrm{~g}$ 이였으나, 효소식 변비군(EL) $0.75 \pm 0.53 \mathrm{~g}$ 
Table 2. Effects of medicinal enzyme powder on body weight gain, food intake and food effciency ratio loperamide-induced constipated rats

\begin{tabular}{lccc}
\hline Groups $^{1)}$ & Body weight gain (g/day) & FER $^{2)}$ & Water intake $(\mathrm{g} /$ day $)$ \\
\hline C & $1.11 \pm 0.74^{3 \mathrm{ab} 4)}$ & $0.04 \pm 0.03^{\mathrm{a}}$ & $26.67 \pm 0.18^{\mathrm{a}}$ \\
CL & $1.72 \pm 0.88^{\mathrm{b}}$ & $0.07 \pm 0.04^{\mathrm{ab}}$ & $24.32 \pm 0.17^{\mathrm{b}}$ \\
E & $1.78 \pm 1.39^{\mathrm{b}}$ & $0.19 \pm 0.06^{\mathrm{c}}$ & $25.08 \pm 0.05^{\mathrm{c}}$ \\
EL & $0.78 \pm 0.53^{\mathrm{a}}$ & $0.06 \pm 0.00^{\mathrm{ab}}$ & $23.67 \pm 0.03^{\mathrm{a}}$ \\
\hline
\end{tabular}

${ }^{1)}$ The Experimental diet groups are as follow. C: normal diet group, CL: normal diet and loperamide-treated group, E : medicinal enzyme powder diet group, EL: medicinal enzyme powder diet and loperamide-treated group.

${ }^{2}$ FER : Food efficiency ratio=body weight gain $(\mathrm{g}) /$ food intake $(\mathrm{g})$.

${ }^{3)}$ Values are means \pm S.D., $\mathrm{N}=10$

${ }^{4)}$ Values with different alphabet within the column indicate significant difference at $p<0.05$ by duncan's multiple range test

Table 3. Effects of medicinal enzyme powder on numble of fecal pellet, wet weight of fecal pellets and fecal water content in loperamide-induced constipated rats

\begin{tabular}{lccc}
\hline Groups $^{1)}$ & Number of fecal pellet (count/day) & Wet weight of fecal pellet (g/day) & Fecal water content $(\%)$ \\
\hline C & $18.58 \pm 0.30^{2)(3)}$ & $1.75 \pm 0.01^{\mathrm{c}}$ & $0.54 \pm 0.01^{\mathrm{d}}$ \\
CL & $13.00 \pm 0.52^{\mathrm{b}}$ & $1.21 \pm 0.03^{\mathrm{a}}$ & $0.28 \pm 0.02^{\mathrm{b}}$ \\
E & $19.38 \pm 0.82^{\mathrm{d}}$ & $2.48 \pm 0.03^{\mathrm{d}}$ & $0.43 \pm 0.01^{\mathrm{c}}$ \\
EL & $9.88 \pm 0.45^{\mathrm{a}}$ & $1.40 \pm 0.15^{\mathrm{b}}$ & $0.22 \pm 0.03^{\mathrm{a}}$ \\
\hline
\end{tabular}

${ }^{11}$ The Experimental diet groups are as follow. C: normal diet group, CL: normal diet and loperamide-treated group, E: medicinal enzyme powder diet group, EL: medicinal enzyme powder diet and loperamide-treated group.

${ }^{2)}$ Values are means \pm S.D., $\mathrm{N}=10$

${ }^{3)}$ Values with different alphabet within the column indicate significant difference at $p<0.05$ by duncan's multiple range test

로 효소식이의 공급으로 $p \times 0.05$ 수준에서 일일 체중증가량 감 소효과를 보였다. 사료효율은 정상식군 $(\mathrm{C})$ 과 정상식 변비군 (CL) 사이에 유의적인 차이는 없었으나 효소식군(E)에 비해서 효소식 변비군(EL)의 사료효율은 $p<0.05$ 수준에서 유의적으 로 낮았다. 그러나 변비군(CL, EL) 식이효율에서는 식이종류 에 따른 영향은 관찰 할 수 없었다. 또한 일일 수분섭취량은 정상식군 $(\mathrm{C})$ 과 효소식군 $(\mathrm{E})$ 과 각각의 변비군 $(\mathrm{CL}, \mathrm{EL})$ 을 비교 했을 때 변비군 $(\mathrm{CL}, \mathrm{EL})$ 에서 유의적으로 낮았으며, 변비군 $(\mathrm{CL}, \mathrm{EL})$ 사이에서는 정상식 변비군 $(\mathrm{CL})$ 보다 효소식 변비군 (EL)의 수분섭취량이 $p<0.05$ 수준에서 더 낮았다.

Park 등[31]은 loperamide로 변비를 3일 동안 유발시킨 결 과 정상식이를 섭취시켰을 때 loperamide를 투여한 군에서 유의적이지는 않지만 사료섭취량이 감소하는 경향을 보였으 며, 최종 일일 체중증가 현상은 없었다고 보고하였다. 그러나 식이 내 loperamide를 $100 \mathrm{~g}$ 당 $0.03 \mathrm{~g}$ 을 첨가시켜 만든 실험 식이를 5 주간 급여한 변비유발 흰쥐의 체중증가는 정상군에 비해 유의적으로 높은 반면에, 식이효율은 낮았다고 $\operatorname{Sin}$ [36] 은 보고하였다. 이러한 결과의 차이는 loperamide 투여방법과 투여기간에 따라서 변비의 심한 정도가 다름으로써 나타난 것으로 추측이 된다. 본 연구에서는 loperamide 투여로 유발 된 정상식 변비군 $(\mathrm{CL})$ 은 정상식군 $(\mathrm{C})$ 에 비해서 일일 체 중증 가량은 $55 \%$, 식이효율은 $75 \%$ 높았다. 그러나 효소식 변비군 $(\mathrm{EL})$ 은 효소식군 $(\mathrm{E})$ 에 비해서 일일 체중증가량은 $42.8 \%$, 식이
효율은 $30.6 \%$ 의 감소를 보였다. 따라서 변비로 인하여 증가된 일일 체중증가량과 식이효율은 효소식이의 공급으로 조절시 킬수 있는 것으로 나타났다.

\section{변 개수, 변 중량, 변의 수분함량 및 장 운동성}

실험동물의 변 개수, 변 중량 및 변의 수분함량 결과는 Table 3 과 같다. 변의 개수는 정상식군 $(\mathrm{C})$ 은 $18.6 \pm 0.30$ 개에 비 해서 변비군 $(\mathrm{CL})$ 은 $13.0 \pm 0.52$ 개, 효소식군 $(\mathrm{EF})$ 은 $19.4 \pm 0.82$ 개 에 비해서 변비군(EL)은 $9.88 \pm 0.45$ 개로 loperamide에 의한 변 비 유발로 $p \times 0.05$ 수준에서 유의적으로 변 배설량이 감소되었 다. 또한 변비군(CL, EL)의 배설된 변의 개수는 정상식 변비군 $(\mathrm{CL})$ 에 비해서 효소식 변비군(EL)에서 $p<0.05$ 수준에서 3.12 개 정도 더 적었다. 변 중량과 수분함량은 정상식군 $(\mathrm{C})$ 과 효소식 군 $(\mathrm{EF})$ 각각의 변비군 $(\mathrm{CL}, \mathrm{EFL})$ 을 비교했을 때 변비로 인하여 $p<0.05$ 수준에서 유의적으로 감소하였다. 실험동물의 장 운동 성 결과는 Fig. 1 과 같다. 그 결과 정상식군(C)에서는 변비유도 (CL)로 $71.3 \pm 0.6 \%$ 에서 $66.5 \pm 8.9 \%$ 로 $6.7 \%$ 의 장 운동성이 $p<0.05$ 수준에서 유의적으로 감소된 반면에, 효소식군(E)에서 는 변비유도(EL) 후 $83.4 \pm 2.1 \%$ 에서 $87.4 \pm 1.3 \%$ 로 효소식이의 공급으로 $p<0.05$ 수준에서 $4.8 \%$ 정도 장 운동성이 유의적으로 증가되었다. 또한 변비군 $(\mathrm{CL}, \mathrm{EL})$ 중에서는 정상식 변비군 (CL) 보다 효소식 변비군(EL)의 장 운동성이 $p<0.05$ 수준에서 높은 것으로 나타났다. 


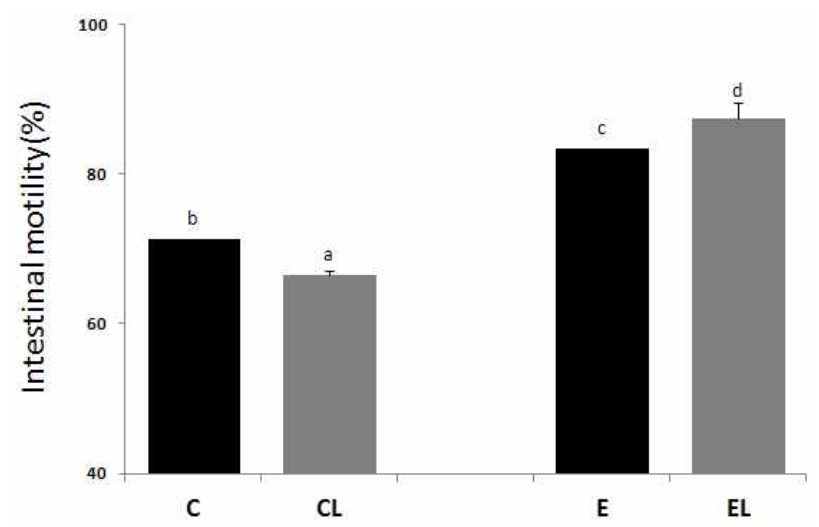

Fig. 1. Effects of medicinal enzyme powder on intestinal motility in loperamide-induced constipated rats. The Experimental diet groups are as follow. C: normal diet group, CL: normal diet and loperamide-treated group, E: medicinal enzyme powder diet group, EL: medicinal enzyme powder diet and loperamide-treated group. Values are mean \pm S.D. of 10 rats per each group and different superscript letters indicate significant differences at $p<0.05$ by duncan's multiple range test.

Loperamide를 일정기간 투여 할 경우 대장관 내 점액질 두께가 얇아지고 장관 내 수분량과 평활근의 운동성 감소 및 위장관 반사 억제로 장 운동이 억제되어 배변시간이 연장되므 로 설사치료제로 이용[33]되고 있으며, 본 연구에서도 loperamide를 투여한 군에서 변의 개수와 변, 변의 수분함량, 그리 고 장 운동성이 감소되는 경향을 보였다. 그러나 loperamide 로 유도된 변비 쥐의 변 개수와 배변량, 그리고 변의 수분 함량 에 있어서 Lee 등[24]은 식이뽕잎 분말의 공급으로, Park [31] 등은 표고버섯 추출액의 공급으로 증가되는 경향을 보였으며, 이러한 효과는 섬유질에 기인한 것으로 설명하였다. 또한 Cho 등[4]은 loperamide를 투여한 흰쥐의 장 기능 개선과 변비 해 소에 함초추출물의 효과를 보고하였으며, Baek [1]은 무의 열 수추출물과 함초추출물에 의한 활성탄의 장 내 이동률을 비교 - 검토한 결과 비슷한 효과 있다고 하였다. 이러한 결과는 식 품 내에 식이 섬유질은 장내 수분 보유력을 증가시켜 직접적 으로 장 내용물의 이동과 장운동의 증가로 숙변과 변비, 비만 을 해결 할 수 있으므로 충분한 식이섬유질을 함유하고 있는 식품은 변비에 이상적인 식품으로 강조되었다.

변비에 대한 식이섬유소와 비슷한 생리적 효과 이외에도 유익한 효과를 보이는 식품소재로 현미, 보리, 대두, 줄풀, 민 들레, 양파, 생지황, 하수오, 이외에 베타글루칸(ß-glucans), 클 로렐라(chlorella), 프락토올리고당(fructooligosaccharide) 등 이 보고 $[6,17,20,37,43]$ 되고 있으며, 본 연구에서는 이들 식품 소재를 이용하여 만든 약선효소 분말을 변비에 이용하였다. 약선효소 식이 중 곡류효소 발효분말 성분인 현미, 보리, 율무, 백태는 섬유소가 풍부하여 대변량 증가 및 장내 통과 시간의 단축, 장내 유익균총의 번식, 그리고 노폐물과 유독 성분의
배출로 대장암을 예방한다고 보고되었다[6, 17, 20,37, 43]. 또 한 약선효소 식물발효 혼합농축액 구성 성분 중에서 줄풀 (Zizania latifolia)은 위와 간장, 비장, 신장이 약한 사람의 정상 적인 장운동을 도와주며[41], 민들레(Taraxacum Officinale)는 비타민과 식이섬유, 섬유질, 미네랄 등이 충분하게 함유되어 있으며 장내 유익한 미생물 균총을 형성하고 장운동을 도와 변비예방에 효능이 있다고 Warren [41]은 보고하였다. 그리고 양파는 위암과 위궤양의 원인인 헬리코박터 파일로리균의 성 장을 억제해 위장 보호와 알린계 휘발 성분이 소화액의 분비 와 장 운동을 활성화시켜 장 무력증에 좋은 효과를 보여준다 [18]. 이외에 예로부터 생지황(Rehmanniae Radix)은 혈열로 진 액이 말라서 딱딱해진 장내 변의 진액 생성, 참당귀(Angelica gigas nakar)는 혈의 부족에 의한 장기능 저하 개선[26, 42] 그리 고 하수오(Polygani radix)는 소장에서 포도당과 아미노산의 흡 수를 높이고 장운동 자극을 통하여 변비를 개선시킨다[21]. 이 중에서 효소적 방법으로 만들어진 2-5개의 당으로 구성된 난 소화성의 저칼로리 감미료인 프락토올리고당은 장내 유용균 인 비피더스균의 증식 인자인 프리바이오틱으로 작용하여 설 사 및 변비예방, 비만예방, 혈중지질 개선 등 식이섬유소와 같은 다양한 기능을 가진다[12]. 또한 기능성 다당체인 베타글 루칸은 항산화 기능을 통하여 노화방지와 아토피 질환을 포함 한 피부병의 개선과 치료 효능 이외에 항암, 면역증강 및 항염 증효과를 보였다[30]. 이러한 효능을 가진 식품소재를 혼합하 여 만든 효소식품은 그 자체가 소화와 대사효소로 이루어져 있으며, 소화효소에 의해 장내 미소화음식물을 분해하고 식이 섬유는 분해되지 않고 남아 있는 장내 잔류물과 유해물질을 체외로 배출하는 기능이 있다고 보고되고 있다[14].

본 연구에서도 loeramide로 유발된 정상식 변비군(CL)은 정상식군 $(\mathrm{C})$ 에 비해서 변 갯수는 $30 \%$, 변 중량은 $30.9 \%$, 그리 고 변의 수분함량은 $48.1 \%$ 의 감소를 보였다. 또한 효소식 변비 군 $(\mathrm{EL})$ 은 효소식군 $(\mathrm{E})$ 에 비해서 변 개수는 $50.9 \%$, 변 중량은 $43.55 \mathrm{~g}$, 그리고 변의 수분함량은 $48.8 \%$ 의 더 높은 감소를 보였 다. 따라서 변비에 의한 변 개수, 변 중량 그리고 변의 수분함 량에 있어서 효소분말의 조절효과는 관찰하지 못하였다. 그러 나 정상식군 $(\mathrm{C})$ 에서는 변비유도 $(\mathrm{CL})$ 로 $6.7 \%$ 의 장 운동성이 감 소되었으나 효소식군(E)에서는 변비유도(EL) 후 $4.8 \%$ 정도의 장 운동성 증가되었다. 이러한 결과는 변비 쥐에게 섭취시킨 약선효소 분말은 식이섬유소가 풍부하며 프리바이오틱과 프 리바이오틱인 식재료의 고유 기능에 효소의 작용이 더 해져서 장 통과 시간을 단축시킨 것으로 여겨진다.

\section{간 기능지표 변화}

실험동물의 혈장 내 간 기능지표 결과는 Table 4에서 제시 한 바와 같이 GOT 활성도는 정상식군 $(\mathrm{C})$ 과 효소식군(E)에 대 하여 각각의 변비군 $(\mathrm{CL}, \mathrm{EL})$ 을 비교했을 때, 정상식군 $32.2 \pm$ $1.21 \mathrm{karman} / \mathrm{ml}$ 에 비해서 정상식 변비군은 $34.0 \pm 1.05$ 
Table 4. Effects of medicinal enzyme powder on serum GOT and GPT activity in loperamide-induced constipated rats

\begin{tabular}{lcc}
\hline Groups $^{1)}$ & $\begin{array}{c}\text { GOT } \\
(\text { karman/ml) }\end{array}$ & $\begin{array}{c}\text { GPT } \\
(\text { karman } / \mathrm{ml})\end{array}$ \\
\hline C & $32.2 \pm 1.21^{2) \mathrm{a} 3)}$ & $24.7 \pm 2.08^{\mathrm{b}}$ \\
CL & $34.0 \pm 1.05^{\mathrm{b}}$ & $23.4 \pm 0.77^{\mathrm{a}}$ \\
E & $35.5 \pm 1.52^{\mathrm{c}}$ & $23.8 \pm 0.98^{\mathrm{ab}}$ \\
EL & $34.2 \pm 2.37^{\mathrm{b}}$ & $25.7 \pm 1.47^{\mathrm{c}}$ \\
\hline
\end{tabular}

${ }^{11}$ The Experimental diet groups are as follow. C: normal diet group, CL: normal diet and loperamide-treated group, E: medicinal enzyme powder diet group, EL: medicinal enzyme powder diet and loperamide-treated group.

${ }^{2)}$ Values are means \pm S.D., $\mathrm{N}=10$

${ }^{3)}$ Values with different alphabet within the column indicate significant difference at $p<0.05$ by duncan's multiple range test

$\mathrm{karman} / \mathrm{ml}$, 그리고 효소식군 $35.5 \pm 1.52 \mathrm{karman} / \mathrm{ml}$ 에 비해 서 효소변비군은 $34.2 \pm 2.37 \mathrm{karman} / \mathrm{ml}$ 로 변비군 $(\mathrm{CL}, \mathrm{EL})$ 에서 $p<0.05$ 수준에서 유의적으로 높았다. 변비군(CL, EL) 사이에 서는 식이에 의한 영향은 없었다. GPT 활성도에서는 정상식 군(C) $24.7 \pm 2.08 \mathrm{karman} / \mathrm{ml}$ 에 비해서 정상식 변비군 $(\mathrm{CL})$ 은 $23.4 \pm 0.77 \mathrm{karman} / \mathrm{ml}$ 로 $p<0.05$ 수준에서 유의적으로 낮은 반면에, 효소식군(E) $23.8 \pm 0.98 \mathrm{karman} / \mathrm{ml}$ 에 비해서 효소식 변비군(EL)은 $25.7 \pm 1.47 \mathrm{karman} / \mathrm{ml}$ 로 $p<0.05$ 수준에서 유의 적으로 높았다. 또한 변비군 $(\mathrm{CL}, \mathrm{EL})$ 간에 비교했을 때 정상식 변비군(CL) 보다 효소식 변비군(EL)에서 GPT 활성도가 $p<0.05$ 수준에서 유의적으로 높았다.

생체 내 GOT와 GPT 활성도는 고지방식, 고콜레스테롤식, 알코올, 약물, 지방 간, 만성변비 등으로 간 기능이 손상되면 이들 효소가 혈 중에 다량 유출 되는 것으로 알려져 있다 [34]. 그러나 본 연구에서 변비 쥐에게 공급한 효소는 소화 · 흡수작용, 유독성분이나 지질성분의 분해 - 배출작용, 항염 · 항균력 통한 면역작용, 간 기능 강화에 따른 해독 - 살균작용, 그리고 혈액정화와 같은 생리작용력이 높은 것으로 알려져 있다[11]. 따라서 이러한 기전을 통하여 변비군에서 증가된
GOT 활성도는 효소식이의 공급으로 다소 낮출수가 있었던 것으로 추측된다.

\section{지질성분 함량 분석}

실험동물의 혈장 내 지질성분 및 동맥경화와 심혈관계 지수 결과는 Table 5 와 같다. 중성지방, 총 콜레스테롤 그리고 LDL콜레스테롤 함량은 정상식군 $(\mathrm{C})$ 과 효소식군(E)과 각각의 변비 군 $(\mathrm{CL}, \mathrm{EL})$ 과 비교했을 때 유의적인 차이는 없었다. 그러나 $\mathrm{HDL}-$ 콜레스테롤 함량은 정상식군(C) $31.2 \pm 7.8 \mathrm{mg} / \mathrm{dl}$ 에 비해 서 변비군(CL)이 $25.4 \pm 3.4 \mathrm{mg} / \mathrm{dl}$ 로 $18.6 \%$ 의 $p<0.05$ 수준에서 유의적인 감소를 보인 반면에, 효소식군(E)과 변비군(EL) 사이 에는 각각 $38.2 \pm 6.5 \mathrm{mg} / \mathrm{dl}, 33.9 \pm 7.3 \mathrm{mg} / \mathrm{dl}$ 로 유의적인 차이 가 없었다. 동맥경화지수 $(\mathrm{AI})$ 는 정상식군 $(\mathrm{C})$ 의 $0.85 \pm 0.46$ 에 비 해서 변비군 $(\mathrm{CL})$ 은 $1.32 \pm 0.51$ 로 $p<0.05$ 수준에서 유의적으로 증가한 반면에, 효소식군(EF)의 $1.03 \pm 0.46$ 에 비해서 변비군 (EL)은 $0.74 \pm 0.44$ 로 $p<0.05$ 수준에서 유의적인 감소를 보였다. 또한 심혈관계 지수 $(\mathrm{CRF})$ 에서도 정상식군 $(\mathrm{C})$ 의 $1.77 \pm 0.52$ 에 비해서 변비군(CL)은 $2.32 \pm 0.51$ 로 $p<0.05$ 수준에서 유의적인 증가를 보인 반면에, 효소식군(E)은 $1.68 \pm 0.75$ 에 비해서 변비 군 $(\mathrm{EL})$ 은 $1.4 \pm 0.57$ 로 유의적인 차이가 없었다. 그러나 변비군 $(\mathrm{CL}, \mathrm{EL})$ 간에 비교했을 때 정상식 보다 효소식 공급으로 동맥 경화와 심혈관계 지수는 $p<0.05$ 수준에서 유의적으로 낮출수 있는 것으로 나타났다.

최근 우리나라 국민의 순환기계 질환에 의한 사망률이 증가 추세로 사회의학적인 문제가 되고 있으며, 이들 질환의 위험 인자로 고열량과 고지방식이와 연결된 고콜레스테롤혈증과 고중성지방혈증, 그리고 흡연, 당뇨, 비만 등으로 알려졌다. 따라서 이들 위험인자를 억제하거나 제거하는 식이에 대한 연구가 활발히 진행되고 있다. 본 연구에 이용된 효소의 $70 \%$ 를 차지하고 있는 원료인 곡류효소 발효 분말 성분으로 현미, 보리, 율무, 백태는 혈중 지질과 지단백(lipoprotein) 농도를 감소시키며 평활근 세포의 전이와 증식을 억제시켜 혈압상승 과 산화적 손상을 방어하여 동맥경화증 억제를 통하여 심혈관

Table 5. Effects of medicinal enzyme powder on serum lipid profiles in loperamide- induced constipated rats

\begin{tabular}{lcccccc}
\hline Groups $^{1)}$ & $\begin{array}{c}\text { Triglyceride } \\
(\mathrm{mg} / \mathrm{dl})\end{array}$ & $\begin{array}{c}\text { Total cholesterol } \\
(\mathrm{mg} / \mathrm{dl})\end{array}$ & $\begin{array}{c}\text { HDL-cholesterol } \\
(\mathrm{mg} / \mathrm{dl})\end{array}$ & $\begin{array}{c}\text { LDL-cholesterol } \\
(\mathrm{mg} / \mathrm{dl})\end{array}$ & $\mathrm{AI}^{2)}$ & $\mathrm{CRF}^{3)}$ \\
\hline $\mathrm{C}$ & $67.4 \pm 22.4^{4) \mathrm{a})}$ & $53.1 \pm 13.2^{\mathrm{NS}}$ & $31.2 \pm 7.8^{\mathrm{b}}$ & $14.35 \pm 8.35^{\mathrm{NS}}$ & $0.85 \pm 0.46^{\mathrm{a}}$ & $1.77 \pm 0.52^{\mathrm{a}}$ \\
$\mathrm{CL}$ & $61.4 \pm 22.3^{\mathrm{a}}$ & $57.6 \pm 8.0$ & $25.4 \pm 3.4^{\mathrm{a}}$ & $19.91 \pm 10.91$ & $1.32 \pm 0.51^{\mathrm{b}}$ & $2.32 \pm 0.51^{\mathrm{b}}$ \\
$\mathrm{E}$ & $83.3 \pm 18.3^{\mathrm{b}}$ & $74.3 \pm 30.5$ & $38.2 \pm 6.5^{\mathrm{c}}$ & $25.95 \pm 20.28$ & $1.03 \pm 0.47^{\mathrm{a}}$ & $1.68 \pm 0.75^{\mathrm{a}}$ \\
$\mathrm{EL}$ & $74.9 \pm 12.7^{\mathrm{ab}}$ & $59.1 \pm 19.6$ & $33.9 \pm 7.3^{\mathrm{c}}$ & $12.93 \pm 12.12$ & $0.74 \pm 0.44^{\mathrm{a}}$ & $1.46 \pm 0.57^{\mathrm{a}}$ \\
\hline
\end{tabular}

${ }^{11}$ The Experimental diet groups are as follow. C: normal diet group, CL: normal diet and loperamide-treated group, E: medicinal enzyme powder diet group, EL: medicinal enzyme powder diet and loperamide-treated group.

${ }^{2)} \mathrm{AI}$ (atherogenic index) $=($ total cholesterol-HDL-cholesterol $) /$ HDL-cholesterol

${ }^{3)} \mathrm{CHR}$ (cardiac risk factor) $=$ Total cholesterol/HDL-cholesterol

${ }^{4)}$ Values are means \pm S.D., $\mathrm{N}=10$

${ }^{5)}$ Values with different alphabet within the column indicate significant difference at $p<0.05$ by duncan's multiple range test 
계 질환을 예방한다고 보고[13, 22, 23, 40,43] 되고 있다. 특히 백미와 달리 다량의 섬유소, 무기질, 비타민, polyphenol, flavonoids, y-oryzanol, phytochemi -cals, phytoestrogen 류 등 다양한 기능성 성분을 함유하고 있는 쌀눈과 쌀겨층의 효과가 검증되면서 건강에 대한 현미 섭취의 중요성이 강조되고 있다 [13]. 특히 Lee 등[22]은 도정된 백미에 비하여 섬유질 함량이 약 2 배 정도 높은 현미는 특히 콜레스테롤의 재흡수 저하와 배설증가로 혈중 콜레스테롤을 낮추는 효과가 보고됨에 따라 서 만성질환에 대한 예방효과가 있다고 하였다. 곡류를 주식 으로 하는 우리나라에서 과거 쌀 다음으로 소비량이 높았던 보리(Hordeum vulgare)는 수용성 식이섬유소인 $\beta$-glucan을 다량 함유하고 있으며, $\beta$-glucan은 콜레스테롤 흡수 저해와 배설을 촉진함으로써 혈중 콜레스테롤을 저하시키는 것으로 동물과 임상실험에서 고콜레스테롤혈증 개선효과가 검증되 었다 $[38,40]$. 한방에서 널리 이용되고 있는 율무 함유생식과 율무약침이 고지방식이를 급여한 흰쥐와 혈액 내 유리지방산 (FFA), 중성지방과 총 콜레스테롤 및 LDL-콜레스테롤 수치는 낮추는 대신에 HDL-콜레스테롤 수치는 증가되는 것으로 보 고되었다[23]. 또한 대두는 이소플라본과 분해산물인 펩타이 드에 의하여 변으로 담즙산의 배설을 증가시켜 혈중 콜레스테 롤을 저하시키며 혈압 강하효과와 혈전 용해효과가 있는 것으 로 보고되었다[40]. 또한 양파와 하수오는 고지방식이를 급여 한 흰쥐의 고지혈증 저하와 혈당강하 작용 $[10,16]$, 그리고 프 락토올리고당과 클로렐라는 혈중 지질개선과 혈당저하 및 비 만개선의 효과가 있는 것으로 나타났다.

본 연구에서도 loeramide로 유발된 정상식 변비군(CL)은 정상식군(C)에 비해서 유의적이지는 않지만 총 콜레스테롤과 LDL-콜레스테롤 함량은 각각 $8.5 \%$ 와 $38.7 \%$ 까지 증가되었으 며, 동맥경화지수와 심혈관지수는 각각 $55.5 \%$ 와 $31.1 \%$ 의 증가 를 보였다. 그러나 효소식 변비군(EL)은 효소식군(E)에 비해서 유의적이지는 않으나 중성지방, 총 콜레스테롤, 그리고 LDL콜레스테롤이 각각 $10.1 \%, 20.5 \%$, 그리고 $50.2 \%$ 의 감소가 나 타났다. 또한 효소식 변비군(EL)은 효소식군(E)에 비해서 동맥 경화지수는 유의적이지는 않으나 $28.2 \%$ 의 감소를, 심혈관계
지수는 $p<0.05$ 수준에서 $50.2 \%$ 의 감소를 보임에 따라서 효소 식이가 변비에 대한 심혈관계 지수에 대하여 보호효과가 있을 것으로 여겨진다.

\section{혈액학적 성분 분석}

실험동물의 혈액 내 단백질, 빈혈 관련 성분 및 혈당 농도 결과는 Table 6과 같다. 혈장 내 총 단백질과 글로불린 농도는 정상식군 $(\mathrm{C})$ 과 정상식 변비군 $(\mathrm{CL})$, 그리고 효소식군 $(\mathrm{E})$ 과 효 소식 변비군(EL)을 비교해서 볼 때 각각 $0.41 \pm 0.12 \mathrm{~g} / \mathrm{dl}$ vs $0.48 \pm 0.1 \mathrm{~g} / \mathrm{dl}$ 그리고 $0.17 \pm 0.11 \mathrm{~g} / \mathrm{dl}$ vs $0.27 \pm 0.08 \mathrm{~g} / \mathrm{dl}$ 로 각 군의 변비군에서 $p<0.05$ 수준에서 유의적인 증가를 보였다. 그 반면에, 알부민 함량은 정상식군(C) $0.15 \pm 0.03 \mathrm{~g} / \mathrm{dl}$ 과 효소 식군(E) $0.22 \pm 0.05 \mathrm{~g} / \mathrm{dl}$ 에 대하여 각각의 변비군 $(\mathrm{CL}, \mathrm{EL})$ 은 $0.20 \pm 0.05 \mathrm{~g} / \mathrm{dl}, 0.24 \pm 0.03 \mathrm{~g} / \mathrm{dl}$ 로 모든 실험군에서 유의적인 차이는 없었다. 헤모글로빈 농도와 헤마토크리트치는 정상식 군 $(\mathrm{C})$ 은 각각 $17.31 \pm 0.65 \mathrm{mg} / \mathrm{dl}, 50.2 \pm 0.69 \%$, 정상식 변비군 (CL)은 각각 $16.84 \pm 2.24 \mathrm{mg} / \mathrm{dl}, 50.4 \pm 6.13 \%$ 로 정상식과 변비 군 간의 헤모글로빈 농도와 헤마토크리트치는 유의적인 차이 가 없었다. 그러나 효소식군(E)의 헤모글로빈 농도는 $18.0 \pm$ $1.23 \mathrm{mg} / \mathrm{dl}$ 에 비해서 효소식 변비군(EL)은 $22.8 \pm 1.69 \mathrm{mg} / \mathrm{dl}$ 로 변비군(CL)에서 $p<0.05$ 수준에서 $27 \%$ 의 유의적인 증가를 보였다. 또한 헤마토크리트치는 효소식군(E)은 $53.9 \pm 6.48 \%$ 에 비해서 효소식 변비군(EL)은 $64.4 \pm 5.13 \%$ 로 변비군(EL)에서 $p<0.05$ 수준에서 $19.5 \%$ 의 유의적인 증가를 보였다. 변비군 $(\mathrm{CL}, \mathrm{EL})$ 에서 효소식이의 영향은 정상식 보다 효소식의 공급 으로 헤모글로빈 농도와 헤마토크리트치를 유의적으로 증가 시켰다. 혈당 농도는 정상식군(C) $138.0 \pm 2.09 \mathrm{mg} / \mathrm{dl}$ 에 비해서 변비군(CL)은 $148.0 \pm 15.8 \mathrm{mg} / \mathrm{dl}$ 로 변비유도로 $7.2 \%$ 의 혈당 농도 증가를 보였다. 그러나 효소식군(E)의 혈당 농도인 $162.3 \pm 12.5 \mathrm{mg} / \mathrm{dl}$ 에 비해서 변비군(EL)은 $144.5 \pm 8.76 \mathrm{mg} / \mathrm{dl}$ 로 $11.5 \%$ 의 유의적인 저하를 보였다. 이때 변비군(CL, EL) 사 이의 혈당 농도는 식이에 의한 영향은 없는 것으로 나타났다.

따라서 본 연구에서는 변비에 의해 저하된 혈액 내 헤모글 로빈 농도와 헤마토크리트치는 효소식이의 공급으로 각각

Table 6. Effects of medicinal enzyme powder on plsam blood parameters in loperamide -induced constipated rats

\begin{tabular}{lcccccc}
\hline Groups $^{1)}$ & $\begin{array}{c}\text { Total protein } \\
(\mathrm{g} / \mathrm{dl})\end{array}$ & $\begin{array}{c}\text { Albumin } \\
(\mathrm{g} / \mathrm{dl})\end{array}$ & $\begin{array}{c}\text { Globulin } \\
(\mathrm{g} / \mathrm{dl})\end{array}$ & $\begin{array}{c}\text { Hemoglobin } \\
(\mathrm{mg} / \mathrm{dl})\end{array}$ & $\begin{array}{c}\text { Hematocrit } \\
(\%)\end{array}$ & $\begin{array}{c}\text { Blood glucose } \\
(\mathrm{mg} / \mathrm{dl})\end{array}$ \\
\hline $\mathrm{C}$ & $0.41 \pm 0.12^{2 \mathrm{a} 3)}$ & $\left.0.25 \pm 0.03^{\mathrm{NS}}\right)$ & $0.17 \pm 0.11^{\mathrm{a}}$ & $17.31 \pm 0.65^{\mathrm{a}}$ & $50.2 \pm 0.69^{\mathrm{a}}$ & $138.0 \pm 2.09^{\mathrm{a}}$ \\
$\mathrm{CL}$ & $0.48 \pm 0.10^{\mathrm{b}}$ & $0.20 \pm 0.05$ & $0.27 \pm 0.08^{\mathrm{c}}$ & $16.84 \pm 2.24^{\mathrm{a}}$ & $50.4 \pm 6.13^{\mathrm{a}}$ & $148.0 \pm 15.80^{\mathrm{b}}$ \\
$\mathrm{E}$ & $0.48 \pm 0.05^{\mathrm{b}}$ & $0.22 \pm 0.05$ & $0.26 \pm 0.06^{\mathrm{c}}$ & $18.0 \pm 1.23^{\mathrm{a}}$ & $53.9 \pm 6.48^{\mathrm{a}}$ & $142.3 \pm 12.5^{\mathrm{b}}$ \\
$\mathrm{EL}$ & $0.46 \pm 0.07^{\mathrm{b}}$ & $0.24 \pm 0.03$ & $0.22 \pm 0.09^{\mathrm{b}}$ & $22.8 \pm 1.69^{\mathrm{b}}$ & $64.4 \pm 5.13^{\mathrm{b}}$ & $144.5 \pm 8.76^{\mathrm{ab}}$ \\
\hline
\end{tabular}

${ }^{1)}$ The Experimental diet groups are as follow. C: normal diet group, CL: normal diet and loperamide -treated group, E: medicinal enzyme powder diet group, EL: medicinal enzyme powder diet and loperamide-treated group.

${ }^{2)}$ Values are means \pm S.D., $\mathrm{N}=10$

${ }^{3)}$ Values with different alphabet within the column indicate significant difference at $p<0.05$ by duncan's multiple range test ${ }^{4)}$ NS: Not significant at $a=0.05$ 
$27 \%$ 와 $19.5 \%$ 의 유의적인 증가를 보였으나, 변비로 증가된 혈 당 농도에 대해서 효소식이의 공급은 아무런 영향을 미치지 못하였다. 이러한 결과는 다이어트로 나타날 수 있는 빈혈 증 상은 효소식이의 공급으로 다소 완화시킬 수 있는 것으로 사 려된다.

\section{감사의 글}

본 연구는 (주) 한국약선 연구비 지원에 의하여 이루어졌으 며 이에 감사드립니다.

\section{Refernces}

1. Baek, Y. H. 2005. A study of dietetic on the constipation. Korean J Herbology 20, 181-191.

2. Bang, M. A., Cho, Y. J. and Kim, H. A. 2002. Effect of Indongcho (L Japonica Thunb) on glucose and lipid metabolism and antioxidative enzyme system in streptozotocin- induced diabetic rats. Korean J Dietary Culture 17, 377-386

3. Burkitt, D. P., Waker, A. R. P. and Painter, N. S. 1974. Dietary fiber and disease. J Am Med Assoc 229, 1068-1074.

4. Cho, Y. S., Kim, S. I. and Han, Y. S. 2008. Effects of Slander Glasswort (Salicornia herbacea $L$ ) extract on improvements in bowel function and constipation relief. J Food Sci 40, 326-331.

5. Corazziari, E. 1999. Need of the drug for the treatment of chronic constipation. Ital J Gasteroenterol 31, 232-133.

6. Fadel, J. G., Newman, R. K., Newman, C. W. and Barres, A. E. 1987. Hypo- cholesterol effects of $\beta$-glucans in different barley diets fed to brolier chicks. Nutr Rep Int 35, 1049-1053.

7. Friedewald, W. T., Levy, R. I. and Fedreicson, D. S. 1972. Estimation of concentration of low density lipoprotein cholesterol in plasma without use of the preperative ultracentrifuge. Clin Chem 18, 449-502.

8. Fuller, R. 1989. Probiotics in man and animal. J Appl Bacterid 66, 365-378.

9. Haglund, O., Loustarinen, R., Wallin, R., Wibell, I. and Sadeen, T. 1991. The effect of fish oil on triglyceride, cholesterol, fibrinogen and malondialdehyde in humans supplemented with vitamin. Eur J Nutr 121, 165-172.

10. Ji, H. J. 1999. Health foods from herbs. Department of food science and nutrition. Ph. D. dissertation. Seoul National University. Seoul, Korea.

11. Jung, J. M., Kim, S. Y. and Jang, S. W. 2007. The power of life - The mystery of the enzyme pp. 58-60, MD Journal. Seoul, Korea.

12. Kawanuchi, M., Tashiro, Y., Adachi, T. and Tamura, Z. 1993. Changes in intestinal condition, fecal microflora and composition of rectal gas after administration of fructooligosaccharide and lactulose at different doses. Bifidibacteria Microflora 12, 57-67.

13. Kim, D. J., Oh, S. K., Yoon, M. R., Hong, H. C., Lee, J. S. and Kim, Y. K. 2010. Antioxidant compounds and antioxidant activities of the $70 \%$ ethanol extracts from brown and milled rice by culivar. J Korean Soc Food Sci Nutr 39, 467-473.

14. Kim, H. C. 2010. Modern people should eat enzyme like rice pp. 86-90, Sogum Namu, Seoul Korea.

15. Kim, H. C., 2010. Modern people should eat enzyme like rice. pp. 49-50, Sogum Namu, Seoul Korea.

16. Kim, J. Y., Seo, Y. J., Noh, S. K. and Cha, Y. J. 2010. A concentrated onion extract lowers serum lipid levels in rats fed a high-fat diet. Korean J Food Preserv 17, 398-404.

17. Kim, J. D. 2012. Literature on the quality and effect of Job's Tears (Coix lachryma -jobi L. Var. mayuen S). J Korean Agricultural History Association 11, 89-121.

18. Kim, J. E., Kim, A. R., Kim, M. J. and Park, S. N. 2011. Antibacterial, antioxidative and antiaging effects of Allium cepa L peel extracts. Appl Chem Eng 22, 178-184.

19. Kim, J. Y., Kim, O. Y., Yoo, H. J., Kim, T. I., Kim, W. H., Yoon, Y. D. and Lee, J. H. 2006. Effects of fiber supplements on functional constipation. Korean J Nutr 39, 35-43

20. Kim, K. H., Chang, J. S. and Oh, Y. K. 2011. Nutrient digestibilities and fecal characteristics of diets including brown rice for Miniature Schnauzer. J Animal Science Tech 53, 429-434.

21. Kim, O. K. 2008. Antidiabetic effect of Ha-Su-O (polygoni radix). J Korean Oil Chemists Soc 25, 347-354.

22. Lee, H. J., Byun, S. M. and Kim, H. S. 1988. Studies on the dietary fiber of brown rice and milled rice. Korean J Food Sci Technol 20, 576-584.

23. Lee, J. M., Lee, S. H., Lee, J. H. and Lee, E. 2006. Effects of Coix lachryma-jobi var. mayuen stapf. pharmacopuncture on plasma lipid composition and glucose in rat fed high fat diet. Korean J Meridian Acupoint 23, 59-86.

24. Lee, J. J., Lee, Y. M., Jung, S. K., Kim, K. Y. and Lee, M. Y. 2008. Effects of dietary Mulberry Leaf in loperamide-induced constipation in rats. Korean Soc Food Preservation 15, 280-287.

25. Martelli, H., Devroede, G., Arhan, P., Duguay, C., Dornic, C. and Faverdin, C. 1978. Some parameters of large bowel motility in normal man. J Gasteroenterology 75, 612-618.

26. Mo, J. H. and Kim, K. R. 2011. The proximate and antioxidative effect of dried and fermented Salicornia herbacea. Korean J Soc Trichologists 7, 425-431

27. Park, H. J., Lee, C. H., Chung, J. P., Lee, K. S. and Lee, S. I. and Park, I. S. 1994. Clinical study of chronic idopathic constipation. Korean J Med 46, 670-680.

28. Park, J. Y., Jang, J. Y., Lee, M. K., Park, E. M., Kim, M. J., Son, D. H., Chung, H. C. and Cho, S. Y. 2002. Effect of Dandelion (Taraxacum Officinale) extracts on the intestinal microorganism of streptozotocin-induced diabetic rats. $J$ Korean Food Sci Nutr 31, 1112-1118.

29. Park, M. I. 2011. Treatment of constipation. Korean J Med 80, 510-523.

30. Park, M. K., Lee, J. M., Park, C. H. and In, M. J. 2002. Quality characteristics of Sulgidduk containing chlorella powder. $J$ Korean Soc Food Sci Nutr 31, 225-229.

31. Park, M. K., Jin, Y. G., Kim, D. G., Jin, J. Y. and Lee, Y. 
J. 2007. Effects of Lentinus edodes extract on the loperamide-induced constipation in rats. Korean J Food Sci Nutr 39, 88-93.

32. Sandler, R. S. and Drossman, D. A. 1987. Bowel habits in young adults not seeking health care. Dig Dis Sci 32, 841-845.

33. Schiller, L. R., Sanat, S. B., Ana. C. A., Moravski, S. G. and Fordtran, J. S. 1984. Mechanism of the antidiarrheal action of loperamide. J Gastroenterology 86, 1475-1480.

34. Seo, B. I., Park, J. H., Choi, H. S., Kim, S. M., Gu, D. M., Kim, M. R. and Park, J. H. 2008. Effects of water extracts from Lagocephalus wheeleri with several herbs on hyperlipidemia and liver damage. Korean J Herbology 23, 9-15.

35. Shimotoyodome, A., Meguro, S., Hase, T., Tokimitsu I. and Sakata, T. 2000. Decreased colonic mucus in rats with loperamide-induced constipation. Comp Biochem Physiol A Mol Integr Physiol 126, 203-212.

36. Sin, H. J. 2008. Effect of dietary resistant starch on the large bowel function in rats with loperamide-induced constipation. Department of food science and nutrition, MS. dissertation. Kyungpook National University. Daegu, Korea.
37. Slavin, J., Jacobs, D. and Marquart, L. 1997. Whole-grain consumption and chronic disease ; protective mechanism. Nutr Cancer 27, 14-21.

38. Stone, B. A. 1986. Cell walls and their components in cereal grain technology. Am Assoc Cereal Chem 8, 116-122.

39. Szajewska, H., Setty. M., Mrukowicz, J. and Guandalini, S. 2006. Probiotics in gastrointestinal disease in children: hard and non-so-hard evidence of efficacy. J Pediatr Gast Nutr 42, 454-475.

40. Tanaka, K., Aso, B. and Sugano, M. 1984. Biliary steroid excretion in rats fed soybean protein and casein or their amino acid mixtures. J Nutr 112, 26-32

41. Warren, J. R. 1983. Unidentified curved bacilli on gastric epithelium in active chronic gastritis. J Lancet 1, 1273-1275.

42. Woo, J. H., Choi, I. Y. and Choue, R. W. 2007. Hematology effects of water extracts of Cham-Dang-Gui on dietary induced iron deficient anemia rat. Korean J Nutr 40, 428-434.

43. Yang, J. L., Lee, S. H. and Song, Y. S. 2003. Improving effect of powders of cooked soybean and chongkukjang on blood pressure and lipid metabolism in spontanecously hypertensive rats. J Korean Soc Food Sci Nutr 32, 899-905.

\section{초록 : 약선효소 분말식이가 Loperamide의 투여로 유발된 변비 쥐의 장 운동과 지질 함량 및 혈액학적 성분 변화에 미치는 영향 \\ 박찬성 · 박경수 · 김미림 · 공현주 · 양경미* \\ (대구한의대학교 한방식품조리영양학부)}

변비는 일상생활에서 식욕저하와 복부 팽만을 일으키며 더 나아가서 피부 노화, 두통, 피부 질환, 그리고 대장 암을 일으킨다고 알려져 있다. 본 연구는 정상식이에 비해 약선효소 분말식이가 loperamide로 유도된 변비 쥐의 장 운동과 간 기능, 지질상태, 그리고 혈액학적 성분에 개선에 대한 효능을 검증하고자 실시하였다. 3 일 동안 loperamide 투여로 유발된 변비 쥐의 일일 체중증가와 사료효율은 높았으며, 이때 효소식이의 공급으로 일일 체중 증가량이 조절되었다. 또한 변비 쥐의 변 개수, 변 중량 및 수분함량, 그리고 장 운동은 정상 쥐에 비해서 감소하 는 경향을 보였으며, 효소식이를 공급시켰을 때 장 운동이 증가되었다. 간 기능 지표인 GOT와 GPT 활성도는 정상식이 섭취군에서는 변비로 인하여 유의적으로 낮은 활성도를 보였다. 그러나 효소식이 섭취군에서는 변비 유도로 GOT 활성도는 증가 된 반면에, GPT 활성도는 감소되었다. 변비 쥐의 혈 액 내 중성지방, 총 콜레스테롤, LDL-콜레스테롤 농도는 효소식이에 의한 저하효과는 없었으나, HDL-콜레스테롤과 동맥경화 및 심혈관계 지수 에 대해서는 효소식이가 보호효과를 보였다. 혈액학적 성분으로 단백질 농도는 변비와 식이에 의한 영향을 받지 않았으나, 변비로 인하여 저하된 헤모글로빈 농도와 헤마토크리트치는 효소식이 공급으로 증가시킬 수 있었다. 이상의 실험 결과에서는 loperamide로 유도한 변비 쥐에서 장 운동성 저하, 동맥경화와 심혈관계지수, 그리고 헤모글로빈농도와 헤마토크리트치 등에 대해서 약선효소 식이가 다소 효과를 보인 것으로 나타났다. 그러나 향 후 만성적 변비에 대한 약선효소 식이효과에 대한 보다 심층적이 연구가 필요하며, 이러한 결과를 바탕으로 변비 에 대한 약선효소 분말과 같은 천연물질의 기능성식품으로 연결된 산업화로 경제적 이익 창출과 변비의 예방으 로 심혈관계 질환과 암의 발병률을 줄이고 변비 대한 식단개발을 위한 기초자료로 활용할 수 있을 것이라고 생각 된다. 